\title{
POSITIVE SOLUTIONS OF M-POINT FRACTIONAL BOUNDARY VALUE PROBLEM ON THE HALF LINE
}

\author{
DONDU OZ AND ILKAY KARACA
}

Abstract. In this paper, six functionals fixed point theorem is used to investigate the existence of positive solutions for fractional-order nonlinear boundary value problems on the half line. As an application, an example is given to illustrate the main result.

Mathematics subject classification (2010): 26A33, 34A08, 34B15, 34B18, 47H10.

Keywords and phrases: Fractional calculus, boundary value problem, fixed point theorem, positive solutions, half line.

\section{REFERENCES}

[1] A. A. Kilbas, H. M. Srivastava and J. J. Trujillo, Theory and Applications of Fractional Differential Equations, North-Holland Mathematics Studies 204 (2006).

[2] C. Zhai AND L. WANG, Some existence, uniqueness results on positive solutions for a fractional differential equation with infinite-point boundary conditions, Nonlinear Anal. Model. Control 22(4) (2017), 566-567.

[3] G. WANG, Explicit iteration and unbounded solutions for fractional integral boundary value problem on an infinite interval, Appl. Math. Lett. 47 (2015), 1-7.

[4] I. Podlubny, Fractional Differential Equations, Academic Press (1999).

[5] I. YASLAN AND M. Gunendi, Positive solutions of higher-order nonlinear multi-point fractional equations with integral boundary conditions, Fract. Calc. Appl. Anal. 19(4) (2016), 989-1009.

[6] J. GRAEF, L. KONG, Q. KONG AND M. WANG, Uniqueness of positive solutions of fractional boundary value problems with non-homogeneous integral boundary conditions, Fract. Calc. Appl. Anal. 15(3) (2012), 509-528.

[7] K. Zhang AND J. XU, Unique positive solution for a fractional boundary value problem, Fract. Calc. Appl. Anal. 16(4) (2013), 937-948.

[8] L. Zhang, B. Ahmad, G. Wang, R. Agarwal, M. Al-Yami and W. Shammakh, Nonlocal integrodifferential boundary value problem for nonlinear fractional differential equations on an unbounded domain, Abstr. Appl. Anal. (2013), Article ID 813903.

[9] M. Dalir And M. Bashaur, Applications of fractional calculus, Appl. Math. Sci. (Ruse) 4 (2010), 1021-1032.

[10] M. REHMAN AND R. A. KHAN, Existence and uniqueness of solutions for multi-point boundary value problems for fractional differential equations, Appl. Math. Lett. 23(9) (2010), 1038-1044.

[11] N. ABEL, Solution de quelques problèmes à I'aide d'intégrales définies, Mag. Naturv 1(2) (1823), $1-27$.

[12] R. Avery, J. Henderson and D. O'Regan, Six functionals fixed point theorem, Commun. Appl. Anal. 12(1) (2008), 69-81.

[13] R. I. AVERY, A generalization of the Leggett-Williams fixed point theorem, Math. Sci. Res. HotLine 3(7) (1999), 9-14.

[14] R. P. Agarwal, D. O’Regan and M. Meehan, Fixed Point Theory and Applications, Found. Phys. Cambridge University Press (2004).

[15] R. W. LEgGetT AND L. R. Williams, Multiple positive fixed points of nonlinear operators on ordered Banach spaces, Indiana Univ. Math. J. 28(4) (1979), 673-688. 
[16] S. BANACH, Sur les opérations dans les ensembles abstraits et leur application aux équations intégrales, Fund. Math 3(1) (1922), 133-181.

[17] S. LiAng AND J. Zhang, Existence of Three Positive Solutions of m-point Boundary Value Problems for Some Nonlinear Fractional Differential Equations on an Infinite Interval, Comput. Math. Appl. (2011), 3343-3354.

[18] W. GE AND X. ZHAo, Unbounded Solutions for a Fractional Boundary Value Problems on the Infinite Interval, Acta Appl. Math. 109 (2008), 495-505.

[19] X. LI, X. LIU, M. JIA AND L. ZHANG, The positive solutions of infinite-point boundary value problem of fractional differential equations on the infinite interval, Adv. Difference Equ. 126 (2017).

[20] X. SU, Boundary value problem for a coupled system of nonlinear fractional differential equations, Appl. Math. Lett. 22(1) (2009), 64-69.

[21] X. YUE AND K. ZHANG, Existence of solution for integral boundary value problems of fractional differential equations, Bound. Value Probl. 151 (2018), 13 pp.

[22] Y. Gholami, Existence of an Unbounded Solution for Multi-Point Boundary Value Problems of Fractional Differential Equations on an Infinite Domain, Fract. Differ. Calc. 4(2) (2014), 125-136. 